\title{
HODROVÁ, URBAN, MACURA - PONOWOCZESNE SPOJRZENIA NA CZESKIE MITY NARODOWE
}

\author{
ANNA GAWARECKA ${ }^{1}$ \\ (Uniwersytet im. Adama Mickiewicza w Poznaniu)
}

Słowa kluczowe: Odrodzenie Narodowe, czeskie imaginarium, demitologizacja

Key words: National Revival, czech imaginary system, demythologization

\begin{abstract}
Abstrakt: Anna Gawarecka. HODROVÁ, URBAN, MACURA - PONOWOCZESNE SPOJRZENIA NA CZESKIE MITY NARODOWE. „PORÓWNANIA” 17, 2015. T. XVII. S. 43-54. ISSN 1733-165X. Po aksamitnej rewolucji 1989 roku literatura czeska, uwolniwszy się z więzów ideologicznego zaangażowania (zarówno w reżimowej, oficjalnej wersji, jak i w postaci dysydenckiego imperatywu demaskowania/oskarżania komunistycznych deformacji i represji) znalazła się w sytuacji, gdy dotychczasowe - obowiązujące od czasów dziewiętnastowiecznego ruchu emancypacyjnego określanego mianem Odrodzenia Narodowego - wyobrażenia na temat zadań i eksponowanej roli pisarza straciły ważność. Sytuacja ta zmusiła twórców do zrewidowania poglądów dotyczących własnej pozycji w społeczeństwie i do ponownego przyjrzenia się dotąd powszechnie respektowanym mitom i stereotypom definiującym czeską wspólnotową tożsamość. W naturalny sposób ich uwaga zwróciła się w stronę epoki kształtowania podwalin narodotwórczego projektu, a zatem w stronę czasów konstruowania odrodzeniowego imaginarium, do dziś w istotnej, choć już nie dominującej mierze dostarczającego narzędzi postrzegania i interpretacji historii i - co za tym idzie - oddziałującego na modele literackiego reprezentowania współczesności. W twórczości Vladimíra Macury, Danieli Hodrovej czy Miloša Urbana imaginarium to zostaje jednak częściowo zakwestionowane i poddane skomplikowanym procesom demitologizacji i uwieloznacznienia.
\end{abstract}

Abstract: Anna Gawarecka. HODROVÁ, URBAN, MACURA - A POSTMODERN LOOK AT THE CZECH NATIONAL MYTH. "PORÓWNANIA" 17, 2015. Vol. XVII. P. 43-54. ISSN 1733-165X. After the Velvet Revolution of 1989 the Czech literature, released from the duty of ideological

\footnotetext{
${ }^{1}$ Correspondence Address: gawarecka@gazeta.pl
} 
commitment (both in its official version and dissident imperative of unmasking/accusing communistic deformation and repressions), faced the situation when hitherto - obvious from the times of National Revival - ideas of tasks and the important role of the writer lost their validity. This situation obliged the artists to reconsider their opinions about the position of writers in society and to reconstruct the system of the traditional myths and stereotypes which until then had defined the Czech collective identity. Their interest was naturally fixed on the beginning of the national project, which means the return to the times of forming the Revival imaginary structure which is still up-to-date, although not dominating, in the area of the interpretation of the history and still influences the literary representation of the present day. In the novels of Vladimír Macura, Daniela Hodrová or Miloš Urban this imaginary structure is partly called in question and brought under the process of demythologization and multiplication of senses.

Vladimír Macura, jeden z najważniejszych i najbardziej opiniotwórczych badaczy czeskiej literatury XIX wieku, we wstępie do swej głośnej pracy Znamení zrodu, budującej semiologiczny model kultury okresu Odrodzenia Narodowego (koniec XVIII stulecia - połowa wieku XIX) przyznaje, że:

V jistém smyslu bude snad náš pohled demystifikační, alespoň v té míre, jako je demystifikační pohled na začátek jako na začátek. Avšak je naším přáním, aby i za žánrem vnuceným autorovým odstupem a snad i za jeho přeintelektualizovanou shovívavostí bylo dobře čitelné čiré dojetí, okouzlení a možná trochu nostalgický smutek... (Macura 1995: 8).

W deklaracji tej uderza z jednej strony podmiotowy i uwzględniający emocjonalne stanowisko stosunek interpretatora do badanych zjawisk, zaskakujący w przypadku zdeklarowanego wyznawcy szkoły strukturalno-semiotycznej, $\mathrm{z}$ drugiej strony zaś - pojawia się $\mathrm{w}$ niej potrzeba usprawiedliwienia zauważalnych w tekście sygnałów odejścia od ustalonych aksjomatów kulturo- i literaturoznawczych, podania ich $\mathrm{w}$ wątpliwość i ukazania propozycji odrębnej - nie tyle zresztą antytetycznej, ile komplementarnej i wzbogacającej.

Książka Macury wydana została po raz pierwszy w 1983 roku, a zatem w czasie, gdy w czeskiej nauce o literaturze nadal i to bezdyskusyjnie panował, respektowany z mocą obligatoryjnego nakazu, obowiązek ujmowania opisywanych zjawisk $\mathrm{w}$ duchu marksizmu spłyconego do dyrektyw reżimowej ideologicznej indoktrynacji. Tymczasem badacz, podążając za Łotmanowską definicją działania mechanizmów kultury (Łotman, Uspieński 147-170), zaproponował koncept Odrodzenia Narodowego oparty na dominacji symboli i emblematów, oddziałujących co prawda na wspólnotową świadomość, ale wyraźnie odległych od realnych wyznaczników praktyki życiowej. Badacz sugeruje przede wszystkim, że w pierwszej połowie XIX wieku samo istnienie narodu czeskiego funkcjonowało jedynie 
w sferze tekstowych reprezentacji, które nie odnosiły się w zasadzie do żadnych (czy niemal żadnych) realnie zachodzących procesów społecznych. Między innymi, Macura rozpatruje w swej pracy zagadnienie mitologiczności, które, jego zdaniem, opisuje podstawowy kanon refleksji wspólnotowej i usuwa w cień wszelkie socjologiczne i polityczne motywacje leżące u podłoża odnowy czeskiej narodowości. Podkreśla przy tej okazji, że:

Obrozenská kultura a celý s ní spojený proces utváření novodobého národa zdá se tíhne $\mathrm{k}$ tomu, vyvolávat $\mathrm{v}$ život ideologické komplexy $\mathrm{z}$ toho či onoho hlediska velmi blízké mýtu (Macura 1995: 79). Mit bowiem, kontynuuje badacz: Představuje svět $\mathrm{v}$ jednotě, nerozčleněný a také nerozčleněně, usiluje ho představit jako celek, nikoliv v dílčí výsečí. Tuto vlastnost mýtu upomíná tíhnutí obrozenské kultury k synkretismu (...), ale současně i snaha sebe samu vidět ne jako část světa, ale jako svět v kostce (Macura 1995: 79).

W oczach Macury zatem, odrodzeniowy projekt przybiera postać mitu scalającego wszystkie ideologiczne i kulturowe komponenty w ujednolicony system, nie zakładający istnienia jakiegokolwiek zewnętrza, zamykający się w obrębie własnych uwarunkowań, usuwający wszelką obcość poza granice jasno zdefiniowanej przestrzeni tego, co swoje i nieakceptujący żadnych heterogenicznych wtrętów.

Mity te, przefiltrowane przez cały system mechanizmów korygujących i skodyfikowane $\mathrm{w}$ dziewiętnastowiecznej literaturze, nadal pozostają miernikiem czeskiej narodowej tożsamości, choć aktualnie, w świecie postmodernistycznego rozchwiania wszelkich pewników, nie stanowią już ostatecznej instancji określającej repertuar wspólnotowych wartości. Jiří Rak w książce Bývali Čechové, poświęconej zagadnieniom czeskiego dziewiętnastowiecznego historyzmu, pisze o roli upowszechnionych wyobrażeń na temat dziejów - ich kształtu, charakteru i interpretacji - które $\mathrm{w}$ największej mierze decydują o zasobie przekonań ogniskujących współczesne postrzeganie rudymentarnych wyznaczników narodowego bytu (Rak 5). Oznacza to między innymi, że fatalizm przeszłości przeradzający się w zmienne współrzędne polityki historycznej do dziś definiuje oblicze czeskiej zbiorowości, wyznaczając zarówno sposoby rozumienia tradycji, jak i projektując ewentualne perspektywy na przyszłość. Owa modyfikacja współrzędnych wypływa zaś przede wszystkim z ewolucji uwarunkowań politycznych, która przyczynia się do zredefiniowania dotychczasowych ustaleń, u jej podłoża leżą jednak również transformacje $\mathrm{w}$ obrębie systemów retorycznych, służących $\mathrm{w}$ pierwszym rzędzie do ewaluacyjnego opisu rzeczywistości i tym samym budujących narodowe imaginarium. W efekcie opowieść o losach dziewiętnastowiecznych budzicieli zyskuje postać apriorycznych schematów narracyjnych, przedustawnie narzucających zarówno strategie porządkowania zdarzeń, jak i wytyczających kierunki ich wartościowania. Jak pisze Hana Šmahelová: 
Náznakový děj, živený hlavně fikcionalitou rétorických prostředků, ustavuje několik základních atributů a konfigurací: jde o osudový zápas, v němž se napravují křivdy minulosti, ale přede vším se rozhoduje o bytí či nebytí národa; přitom stojí proti sobě na jedné straně cizí a nepřátelští nositelé zla, na straně druhé hrdinové Bohem vyvolení, obdaření nadpozemskými vlastnostmi, bojovníci za pravdu a spravedlnost (Šmahelová 19).

Choć propozycja Šmahelovej w wielkiej mierze opiera się na polemice z uznawaną za miarodajną koncepcją Macury, to w obu przypadkach wyeksponowana zostaje owa charakterystyczna dla refleksji odrodzeniowej tendencja mitotwórcza, która powoduje, że wielowątkowość i poliwalencja wydarzeń historycznych podlega schematyzacji w ramach wyraziście antytetycznego pod względem aksjologicznym modelu.

Z punktu widzenia rozważań nad przykładami dezaktualizacji i podtrzymywania narodowych mitów w polistopadowej literaturze czeskiej mniej istotną rolę odgrywa sam polemiczny dialog między uczonymi rozpatrującymi to samo zagadnienie badawcze, ważniejsza wydaje się natomiast potrzeba nowego - kwestionującego dotychczasowe aksjomaty - odczytywania budzicielskiej epoki. Zarówno Macura, eksponujący znakowy charakter Odrodzenia Narodowego, jak i Šmahelová odnajdująca poparcie dla swych tez w teorii rewolucji naukowych Thomasa Kuhna (Šmahelová 132-135), dążą do zmiany obowiązującego dotąd spojrzenia na kluczowy dla wspólnotowej tożsamości naszych południowych sąsiadów paradygmat wyobrażeniowo-światopoglądowy, który ukonstytuował się w pierwszej połowie XIX wieku. Dążenia te dowodzą pośrednio ponadczasowej trwałości tego paradygmatu, prowokującej badaczy do prób podawania w wątpliwość jego historycznej wiarygodności.

Bardziej bezpośrednich dowodów na ową trwałość doszukiwać się należy w ponowoczesnej literaturze, chętnie po 1989 roku powracającej do tematyki odrodzeniowej. Nie są to najczęściej powroty łatwe i bezproblemowe. Towarzyszy im niejednokrotnie refleksja historiozoficzna, przypominająca nierzadko zasługi dziewiętnastowiecznych vlastenców (patriotów), ale nieunikająca też oskarżeń czy rewizji dokonań najważniejszych przedstawicieli czeskiego ruchu emancypacyjnego. Najdosadniej być może zastrzeżenia te wyraził Milan Kundera, który, rekapitulując wydarzenia z Sierpnia 68', włączył je w tradycję czeskiej refleksji tożsamościowej:

Myślałem wtedy często o okresie czeskiego odrodzenia narodowego - odrodzenia, które pośrodku wzburzonej Europy sypało swój mały kopczyk piasku; odrodzenia, które swym oświatowym batem smagało Máchę; odrodzenia niezdolnego do stworzenia wartości ogólnoludzkich; odrodzenia wypełnionego drobną działalnością i wypranego z wielkich czynów. Myślałem o dziedzictwie tej „przeciętności“, którą Czesi wnieśli w wiek XX (Kundera 103). 
Co prawda autor w swych rozważaniach ukazuje zaskakująco pozytywne dla zaktywizowania wspólnotowych postaw zmiany, które wywołała interwencja wojsk Układu Warszawskiego, ale diagnoza i tak jest miażdżąca.W podobny sposób, choć nie posuwając się do równie surowych ocen, rzecz ujmuje Josef Jedlička, który w cyklu, szeroko zresztą w swoim czasie komentowanych, esejów stara się zrekonstruować modelowy typ czeskiego bohatera literackiego, uosobiającego wzorzec respektowanych przez wspólnotę wartości. We wstępie do tych rozważań autor przyznaje, że:

At' už dáme tomu předznamenání znamení kladné nebo záporné, faktem zůstane, že česká kulturní tradice, a tedy ani česká literatura nemá skutečného hrdinu. (...) Už naši obrozenci z toho měli pocit méněcennosti a těžkou hlavu. (...) Připadalo jim, že i my máme právo na své Nibelungy či na české „chansons de geste“, a když nenašli při nejlepší vůli po hrdinských zpěvech ani stopy, sestrojili k všeobecnému užitku Záboje, Slavoje, Zbyhoně a ješte asi půl tuctů národních reků. Piše se o konstruktérech této nacionální mytologie jako o idealistických a rafinovaných falzifikátorech, ve skutečnosti však byli patrně sami tak pevně přesvědčení, že hrdinské písemnictví musí být součástí každé národní kultury, že když svá falza vyráběli, nahrazovali podle svého nejlepšího přesvědčení pouze to, co se z dopuštění osudu nedochovalo (Jedlička 9).

Badacz przenosi całe zagadnienie ze sfery politycznych diagnoz w płaszczyznę literackiego dyskursu, przypominając o spotęgowanej w Czechach (w porównaniu z literaturą innych narodów) kulturotwórczej roli piśmiennictwa, które, w początkach Odrodzenia Narodowego nie tylko opisywało czy kodyfikowało, ale czasami w ogóle zastępowalo wszelkie inne formy życia i działania konsolidującej się dopiero wspólnoty.

Jedlička, przypominając o dziewiętnastowiecznych literackich mistyfikacjach, nawiązuje do jednego ze sztandarowych czeskich mitów założycielskich, a mianowicie do "odkrycia“ w roku 1817 przez Václava Hankę dwóch rzekomo średniowiecznych rękopisów (Královédvorský rukopis; Zelenohorský Rukopis; w skrócie RKZ) zawierających fragmenty staroczeskiej poezji epickiej i lirycznej. Wiara $\mathrm{w}$ autentyczność tych tekstów, stanowiących w istocie wyjątkowo starannie sfabrykowane palimpsesty (w sensie techniki wykonania) w mistrzowski sposób i zgodnie z ówczesną wiedzą mediewistyczną naśladujące zarówno ruskie i serbskie, jak i zachodnioeuropejskie pieśni bohaterskie, przez długi czas traktowana była jako wyznacznik i probierz patriotycznego odczuwania, mimo iż od początku autentyczność ta budziła też poważne wątpliwości (Macura 1995: 109-111; Nawrocki 38). Zdemaskowanie fałszerstwa nastąpiło dopiero $w$ osiemdziesiątych latach XIX w., w atmosferze burzliwych sporów, w których, jak podkreśla Miloš Urban:

Obě strany problém pravosti důsledně politizovaly. Obhájci vášnivě argumentovali národními zájmy a nezř́ídka sklouzli do nacionálně šovinistických pozic. Odpůrci ape- 
lovali o rozum a objektivitu, šlo jim o dobré jméno české vědy za hranicemi; nevíra v Rukopisy byla pro ně znakem pokrokovosti (Urban 1998: 19).

Wypowiedź ta pochodzi z debiutanckiej, zatytułowanej Poslední tečka za rukopisy (1998), powieści pisarza, znanego dziś głównie jako autor postmodernistycznych thrillerów o tematyce historycznej. W powieści tej Urban uderza nie tyle $\mathrm{w}$ samą, do dziś zresztą $\mathrm{w}$ niektórych kręgach podtrzymywaną, iluzję autentyczności rękopisów, ile $\mathrm{w}$ parodystyczny sposób rozprawia się $\mathrm{z}$ rozpowszechnioną w ostatnim czasie modą na literacką pseudofaktografię, opartą na nie w pełni potwierdzonych przesłankach i na poziomie hipotez umiejętnie manipulującą "pustymi miejscami“ w ustaleniach historyków². Łącząc podbudowane rzetelną wiedzą wnioski z mniej lub bardziej prawdopodobnymi domysłami i fabrykując dokumenty, Urban proponuje tu alternatywną historię czeskiego Odrodzenia Narodowego, w której nawarstwiające się mistyfikacje zacierają rzeczywisty wymiar wydarzeń i obnażają nieoczywistość utartej wykładni dziejów. Quasi-naukowy charakter obszernych fragmentów tekstu sprawia, że absurdalne konkluzje dwójki bohaterów - skądinąd pracowników naukowych Instytutu Literatury Czeskiej praskiego uniwersytetu - zyskują (oczywiście w ramach powieściowej fikcji) znamiona wiarygodności, a tytułowe „ostatnie słowo" w sprawie rękopisów, staje się słowem opatrzonym mocą kreowania rzeczywistości:

Prohlašujeme, že jmenované rukopisy jsou skutečnými památkami krásného písemnictví středověkých Čech. (...) Desítky generací znaly ony dvě osoby nejtěsněji spjaté s Rukopisem královédvorským a Rukopisem zelenohorským, jejich údajné padělatele, pod jmény Václav Hanka a Josef Linda. Naše habilitační práce tento omyl vyvrací. Hanka a Linda neexitovali. Hanka a Linda existovaly. Jmenovaly se Hannelore Vierteilová a Linda Janovitzová (Urban 1998: 189-190, 191).

Wyraźne włączenie "tajemnicy rękopisów“ w dyskurs genderowy, potwierdzone całkowicie niezgodnym ze znanymi faktami „zaangażowaniem“ w misternie zaprojektowaną intrygę ważnych „kobiet pióra“ Odrodzenia Narodowego Magdaleny Dobromily Rettigovej (autorki pierwszej książki kucharskiej napisanej po czesku) i nieżyczliwie tu przedstawionej Boženy Němcovej - najwybitniejszej czeskiej prozaiczki XIX wieku i patronki ruchu feministycznego, ostatecznie

${ }^{2}$ Por.: „My noví autoři, jsme připraveni beze studu strhnout nažehlené zaštěrky „hledačů pravdy“" za nimiž se s brutálním naturalismem rýsuje nepřehlednutelně nahý, filozofy dávno poznaný fakt, že jediná pravda neexistuje a je marné ji hledat. Jsme přesvědčeni, že i kdyby se někde za rohem přece jen skrývalo poslední neodhalené metafyzické „něco“ - nebot' člověk nikdy neví -, někdo by jeho zvěstování světu tak jako tak zneužil k postranním účelům a rozmělnil k nepoznání. Jsme $\mathrm{s}$ tím srozuměni a počítáme s tím. Svým dílem se stavíme proti autorům literatury faktu, kteří se ve své posedlosti chimérickou "pravdou“ či „skutečným stavem věcí“ nikdy neodvážili postavit tváří v tvář faktům nejprostším: faktům života" (Urban 1998: 36). 
ośmiesza wszelkie spiskowe teorie towarzyszące zbyt daleko posuniętym egzegetycznym ingerencjom w materię dziejów ${ }^{3}$.

W później opublikowanych powieściach (Sedmikostelí, 1999; Hastrman, 2001; Pole i palisáda, 2006) Urban wraca do poszczególnych komponentów mitologii skodyfikowanej w ideowym porządku Odrodzenia Narodowego, by przyjrzeć im się krytycznym okiem i otworzyć drogę ku ich „heretyckim” interpretacjom. Zwłaszcza w pierwszej z tych powieści, w Polsce opublikowanej pod dość mylącym, choć przyciągającym uwagę czytelnika, tytułem Klątwa siedmiu kościołów, opowiadającej w utopijnej konwencji o pełnej restytucji w Pradze zasad i warunków życia z epoki przedhusyckiego średniowiecza, narrator - mediewista i zwolennik dziejopisarstwa nastawionego na ewokację codzienności - stwierdza w teoretycznych komentarzach:

Barbarství armád nikdy nezklame - ve všech dobách má podobnou tvár̆. Vojsko se v servitském klášteře Na Slupi usadilo už koncem století osmnáctého, poté, co byl na př́kaz císaře Josefa zrušen. Posádka dělostřelců a chovanci vzdělavacího ústavu Kinského a Kallenbergova pluku rádili $\mathrm{v}$ odsvěceném kostele jako $\mathrm{v}$ dobytém území neprrítele: (...). Ale co to bylo proti podzimu 1420, kdy odsud, př́imo z chrámu Páně, stř́leli husité na Vyšehrad! (Urban 1999: 133-134).

Pierwsza część tej wypowiedzi w pełni koresponduje z tradycyjną refleksją dotyczącą wartościowania wydarzeń historycznych, stereotypowo przypisując destrukcyjną rolę pierwiastkowi germańskiemu (w tym przypadku oddziałom austriackim). Jej druga część jednak owo zakorzenione w świadomości zbiorowej myślenie radykalnie opuszcza. Przypomina bowiem, tuszowane konsekwentnie w owej refleksji, negatywne dla czeskiego bytu narodowego rezultaty husyckiej rewolty. Jej apologetyczne ujmowanie przynależy zaś do podstawowego kanonu odrodzeniowych aksjomatów, do dzisiaj rzutujących w Czechach na postrzeganie "jasnych“ i „ciemnych" stron narodowej przeszłości. Wniosek wypływający z tych rozważań wydaje się w efekcie nie tylko zaskakujący, lecz również obrazoburczy, uderza bowiem w przekonania najbardziej utrwalone we wspólnotowej pamięci. Wbrew pozorom jednak Urbanowska ocena nie odbiega od ustaleń dwudziestowiecznych historyków, którzy nie unikają już wskazywania katastrofalnych dla czeskiej kultury (zarówno duchowej, jak i materialnej) konsekwencji husyckiego

${ }^{3} \mathrm{~W}$ pracy Urodzić naród. Z problematyki czeskiej i stowackiej literatury kobiecej II połowy XIX wieku Marcin Filipowicz zwraca na przykład uwagę na niebezpieczeństwa związane z narzucaniem dziewiętnastowiecznym pisarkom dzisiejszego „światopoglądu feministycznego". „Podobne próby [...] pisze - podejmowane [...] przez badaczy, są schematyczne i ograniczają się do określenia pisarki jako pierwszej czeskiej feministki, bojowniczki o feminizm itp. Są to hasła niepotwierdzone żadną gruntowną analizą, która byłaby przeprowadzona z uwzględnieniem założeń feministycznej krytyki literackiej. [...] Takie aprioryczne uznawanie Němcovej za feministkę jest dużym uproszczeniem i wpisuje się w nurt krytyki, który można określić jako socrealizm feministyczny" (Filipowicz 18-19). 
ikonoklazmu. W tym przypadku zatem Urban polemizuje przede wszystkim z zespołem stereotypowych przeświadczeń, budowanych, jak sądzi Jiří Rak, na podstawie ograniczonej skali

nejrůznějších apriorních soudů, poznatků získaných ponejvíce $\mathrm{z}$ mimovědeckých zdrojů - ze vzpomínek na školní výuku, z četby historických románů (v moderní době je ovšem dominantním a nejúčinnějším zdrojem pro vytvoření historického povědomí film a televize), z průvodcovských výkladů př́i návštěvách historických památek, z domácího a regionálního podání atd (Rak 5).

Literatura z podobnych zakorzenionych $\mathrm{w}$ świadomości społecznej stereotypów czerpie inspirację, czasami bezkrytycznie za nimi podążając, w innych przypadkach zaś czyniąc $\mathrm{z}$ nich przedmiot procesów demistyfikacyjnych i narzędzie zakwestionowania narodowej mitologii, podania w wątpliwość jej centralnych aksjomatów oraz proponowania rozwiązań odmiennych.

Co więcej, czescy pisarze, tradycyjnie, właśnie od czasów Odrodzenia Narodowego, przyzwyczajeni do pełnienia funkcji duchowych przewodników i nauczycieli zbiorowości, z trudem pogodzili się ze, spowodowaną przemianami politycznymi roku 1989, utratą tej wyeksponowanej pozycji i degradacją siebie do roli dostarczycieli bezinteresownej i niezobowiązującej rozrywki. Jiří Kratochvil, jedyny w Czechach prozaik otwarcie przyznający się do postmodernistycznych założeń swego warsztatu twórczego, twierdzi, że znamion owej straty pozycji dopatrywać się należy w rezygnacji (raczej trzeba przyznać wymuszonej i nie w pełni zaakceptowanej) z podejmowania pozaartystycznych zadań, które dotąd określały rangę literatury $\mathrm{w}$ czeskim społeczeństwie, ale podkreśla przy tym, że to zejście z piedestału rekompensowane jest uzyskaniem pełnej i absolutnie niczym niekontrolowanej swobody kreacyjnej. Dzięki temu, zdaniem Kratochvila, pisarze:

Nejenže se vědomě a programově vracejí $\mathrm{k}$ literatuře artistní a artificielní (...), ale především směřují k vytváření jakýchsi individuálních literárních mýtů, střídajících mýty kolektivní, které dosud dominovaly v české literatuře, od času obrozenských přes levicové avantgardy až po literaturu angažovanou a literaturu "politické opozice“ šedesátých let (Kratochvil 84).

W przypadku Macury, Urbana czy Danieli Hodrovej jednak ta prywatna mitologia uwzględnia również dotychczasowe konstrukty mitotwórcze, obejmujące zarówno odrodzeniowe imaginarium, jak i nieuciekające przed prowokowaniem opinii publicznej. Sięganie po budzicielskie motywy i stereotypy przynależy bowiem do "żelaznego repertuaru“ czeskich postmodernistycznych gier z historią, nastawionych na demontaż utrwalonych poglądów i sposobów ich literackiej reprezentacji.

W latach dziewięćdziesiątych, w tetralogii powieściowej Ten, který bude, Macura przetransponował naukowe ustalenia w świat fikcji literackiej, bliższej potocz- 
nemu doświadczeniu i zacierającej modelowy charakter teoretycznego konstruktu. Pisarz dokonuje tutaj zatem swoistego eksperymentu, weryfikując działanie swych semiologicznych konkluzji w praktyce życia codziennego budzicieli. Obnaża prywatne i często niskie motywacje stojące za pozornie wzniosłymi i patriotycznymi pobudkami i demonstruje na przykładach konkretnych ludzkich losów, jak pierwotny entuzjazm czy choćby ciekawość i chęć poznania środowiska patriotycznego przeradza się w rozczarowanie lub obojętność. Zamiast legendarnych „męczenników sprawy narodowej" czytelnik zyskuje portrety intrygantów, życiowych rozbitków i nieudaczników lub, z innej strony patrząc, fanatycznych dogmatyków, niedopuszczających do żadnej dyskusji $\mathrm{z}$ odmiennymi punktami widzenia i w końcu (jak w ostatnim tomie cyklu zatytułowanym Medicus) - szaleńców, $\mathrm{w}$ których rojeniach rodzą się zręby historii alternatywnej. W pierwszej części tetralogii (Informator) bohater, skrachowany inteligent i niedobrowolny agent austriackiej policji, przybywa do stolicy Czech, mając nadzieję na odzyskanie pozycji społecznej i na zdobycie miłości Antonii Rajskiej (1817-1852), jednej z najważniejszych działaczek ruchu narodowego. Spotkanie z miastem, często w odrodzeniowej literaturze prezentowane jako inicjacyjny moment „przejścia na czeską wiarę", nie przynosi jednak spodziewanej epifanii. Zamiast tętniącej społecznym życiem metropolii odpowiadającej na wyzwania współczesności, protagonista - powielając skądinąd w swych rozmyślaniach semiologiczne konkluzje autora powieści odnajduje wśród miejskich murów jedynie wyjałowione z aktualnej treści znaki dawno umarłej świetności:

Vůbec se tu cítil v Praze jako v kostnici. Všechno kolem jako by bylo stavěno z kostí. Dům po domu. Palác vedle paláce. Samá kost. I ten Steinbrücke, lemovaný ohlodanými sochami světců. (...) Co znamenají ty stavby kolem, sloupy, budovy, chrámy? No přece signum. Místo, kde poslušný český kat st́al neposlušné české pány. Místo, kde kázal Mistr Jan. Kde se propadla Drahomíra do pekel. Kde zamordovali fanatika Želivského. Kde Libuše vařila čarodějné lektvary. Signum na signum. Kost na kost. A ti lidé kolem? Holé skelety. Neměl si z nimi nic začínat. Ǩíkal si muž. Ale už se stalo. Začalo to všechno docela nevinně. Zapomněl být ve střehu (Macura 1999: 36, 38-39).

Za tym atakiem na jeden z pierwszoplanowych emblematów czeskości - przekształcone w alegorię miasto - stoi podanie w wątpliwość całego odrodzeniowego konglomeratu symboli. Bohater Informatora nie zyskuje, co prawda, sankcji autorskiej, ale to jego punkt widzenia dominuje nad innymi przywoływanymi w dziele stanowiskami i to on w ostatecznej instancji decyduje, jakie tezy światopoglądowe i konkluzje interpretacyjne dotrą do odbiorcy. Od czytelnika zależy zaś, czy - wyposażony w zasób stereotypowej wiedzy i utartych przekonań - zaakceptuje potencjalną "propozycję alternatywną" i zgodzi się na reinterpretację najbardziej opiniotwórczego okresu czeskiej historii, czy pozostanie przy dotychczas wyzna- 
wanych przeświadczeniach, uznając bohatera za pozbawionego kręgosłupa moralnego pieczeniarza i sprzedawczyka.

$\mathrm{W}$ analogicznym duchu, poddając odrodzeniowe mity mechanizmom dekonstrukcyjnym, postępuje Daniela Hodrová w powieści Podobojí, gdzie stematyzowana refleksja na temat narodowych dziejów wpisana zostaje w skomplikowaną opowieść o podwójności bytu, w której wszystkie formy istnienia zyskują swój pendant $\mathrm{w}$ świecie pośmiertnym. Refleksja ontologiczna znajduje tu uzupełnienie w rozważaniach historiozoficznych, a swoista, bo pozbawiona metafizycznych uzasadnień, sytuacja wiecznego trwania powoduje, że dawne wydarzenia historyczne stają się prefiguracją wydarzeń późniejszych, w których przeszłość powraca w zdegradowanej i nierzadko karykaturalnej formie:

Obrodný proces na Olšanském hřbitově pokračuje (...). Pan Klečka, jak se tak ve dne potuluje mezi hroby, nachází jeho další a další neklamné známky. Všimne si, že pan Šafařík se začal shánět po panu Palackém (kampak se poděl otec národa?) a mluví cosi o vládě bodáků a špěhů, která do hrobu klesá. Pan Kollár teskní po Míně, i když dávno spí po jeho boku, a pan Jungmann vede na hrobech rozmlouvání o jazyce českém. A všude kolem vzniká plno hřbitovní poezie. A pan Klečka z toho pochopí, že zase začíná národní obrození. A jednoho dne potká pana Havlíčka, který se něčemu ironicky usmívá (Hodrová 83)4.

Cmentarz na Olšanach - najbardziej znane narodowe sanktuarium - należy w świecie powieści Hodrovej do wyjątkowo eksponowanych przestrzeni ontologicznej nieokreśloności. To $w$ tej nekropolii dochodzi do przemieszania rozmaitych form bytu i to tu „zwykli” mieszkańcy dwudziestowiecznego świata mogą na równych prawach obcować z legendarnymi przedstawicielami Odrodzenia, którzy - zasklepieni w więzieniu własnych biograficznych doświadczeń - nie potrafią odnaleźć się w nowej sytuacji historycznej, spoglądając na nią przez pryzmat budzicielskiej mitologii. Tymczasem, jak wynika z powieściowych refleksji, mitologia ta, choć nadal nie traci aktualności, ma też swe „ciemne miejsca”, owe "przestrzenie podoboji", $\mathrm{w}$ których niekwestionowana dotąd jednoznaczność ocen zderza się $\mathrm{z}$ ambiwalencją i relatywizmem spojrzenia zrodzonego dzięki upływowi czasu i przyrostowi bagażu wiedzy o historycznych przemianach:

${ }^{4}$ Wypowiedź ta odnosi się do odwilżowego procesu z lat sześćdziesiątych. W analogiczny sposób w powieści zasygnalizowane zostają wydarzenia z sierpnia roku 1968: Pan Klečka se jde jednou za letní noci jako obvykle nadechnout hřbitovního vzduchu. A zase potká pana Havlička. Pan Havliček se tentokrát už neusmívá a ke všemu pana Klečku neočekávaně osloví. Dokonce mu řekne př́teli a že je zle [...]. Hůře bude než zle. Pan Havliček totiž tuši, že co nevidět prìtáhne Windischgrätz, v Praze se zase budou stavět barikády... A dokonce se panu Havlíčkovi zdá, že už slyši dunět zem pod Windischgrätzovou artilerií. A vyzve pana Klečku, aby přiložil ucho $k$ zemi a poslechl, jestli už nejedou. Pan Klečka přiloži ucho k olšanské zemi a poslouchá. A opravdu slyší, jak země duní, jako by se dole měla rozevř́t propast, Jan Paskal by řekl Gehenna (Hodrová 91-92). 
Pana Klečku setkání s panem Sabinou přece jen uvedlo do poněkud skleslé nálady a nedokaže ji přemoci ani večer před panem Turkem. A nakonec panu Turkovi vypoví všechno - o národním obrození, o panu Šafaříkovi, o panu Kollárovi, o panu Jungmannovi, o všech se přece učili ve škole (...). A pan Klečka se také zmíní o panu Havlíčkovi, že se něčemu ironicky usmíval. (...) Klečka se dlouho rozmyšlí, má-li se zmínit také o panu Sabinovi, aby se toho pan Turek nechytil a zase na to neřekl - Jakápak obroda, když je všude kolem plno všelijakých Šípků, i tady na hřbitově. (...) A pak řekne kupodivu něco úplně jiného: Tak tady to máš, to své obrození. Nechali ho chcípat hlady, a když prodal vlastní kuži,tak nad ním svorně vyřkli ortel (Hodrová 84).

„Czarna legenda“ budzicieli - dzieje "zdrady“ i kolaboracji romantycznego poety, Karla Sabiny, jednego z mieszkańców olszańskiego cmentarza, staje się oskarżeniem całego Odrodzenia Narodowego, które pozwoliło swym koryfeuszom „umierać z głodu“ (a taki los, należy podkreślić, spotkał zarówno Boženę Němcovą, jak i twórcę czeskiego hymnu, Josefa Kajetána Tyla), by później w zależności od politycznej koniunktury - bądź w akcie spóźnionej ekspiacji urządzać im uroczyste pogrzeby (w przypadku Němcovej i Tyla), bądź odsądzać ich trudne i wymuszone okolicznościami życiowe wybory od czci i wiary. W efekcie Hodrová manifestacyjnie przysądza ową tendencję do obosieczności postaw czeskiemu narodowi, rozumianemu jako ideologiczny konstrukt wypracowany zarówno przez odpowiednio spreparowaną pamięć historyczną, jak i potoczne doświadczenia członków wspólnoty, niejednokrotnie zmuszonych do lawirowania między respektowaniem imperatywów etycznych a koniecznością podporządkowania się aktualnym uwarunkowaniom politycznym i społecznym:

Jsem národ. Upadl jsem v nové egyptské zajetí. Vyznávám víru podobojí, přijímám tělo a krev Paně. (...) Mám své revoluce a své hrdiny. Jeden z nich vzplál na hranici, kterou si sám navršil - mezi Národním muzeem a Domem potravin.(...) Jsem národ vystřizlivělý ze svých revolucí a svých zápalných obětí. Jsem národ, který konvertoval (Hodrová 104).

Naród, który sprzeniewierzył się ideałom, leżącym u podłoża procesu prowadzącego do jego emancypacji, nie zasługuje już na ochronę płynącą ze strony powszechnie respektowanego mitu. Dlatego też, być może, Hodrová poddaje poszczególne części składowe czeskiej mitologii - na przykład legendę o rycerzach śpiących w górze Blaník - ironicznemu przewartościowaniu, dowodzącemu jej nieadekwatności w stosunku do aktualnie panującej sytuacji:

A tak by to asi bylo i s těmi rytíři, kdyby jednou vyšli, až by v Čechách bylo nejhưře, a také se svatým Václavem na bílém koni, který by jel v čele. Všichni by byli staří a k nepotřebě a vrátili by se do hory a zůstali by v ní na věčnou památku (Hodrová 28$)^{5}$.

${ }^{5} \mathrm{O}$ roli mitu blanickich rycerzy dla systemu imaginacyjnego Odrodzenia Narodowego szeroko pisze V. Macura w pracy Český sen (Macura 14-47). 
Jednak nawet naród, który dokonał konwersji i utracił pierwotną wiarę, potrzebuje zakorzenienia $\mathrm{w}$ trwałych i niezmiennych przestrzeniach zorganizowanych w ramach porządku mitu. Jak bowiem dowodzi Leszek Kołakowski:

Dziedziczenie mitów jest dziedziczeniem wartości, które mit narzuca. Spójność współbytowania ludzkiego wymaga tedy, by tradycja jako taka - nie przez to, iż uprzednio oceniona została jako dobra tradycja - promieniowała autorytetem. Nie wynika stąd jeszcze, by wartości mitu były w całości immanentne wobec tych wartości, które mit przekazuje, a które są zbiorowościom ludzkim potrzebne. Nie wynika również, by należało czcić bez zastrzeżeń tradycję. Poszczególne tradycje są żywotne lub tracą energię i obumierają w zależności od mnóstwa okoliczności; żyją i giną jak ludzie (Kołakowski 13-14).

Czescy twórcy sięgają zatem po narodowe mity, nieważne, że czasem w formie zdegradowanej, ośmieszonej czy subwersyjnej, dlatego że w zbiorowym imaginarium są one nadal żywe i stale oddziałują na konstruowanie indywidualnej i wspólnotowej tożsamości.

\section{BIBLIOGRAFIA}

Filipowicz, Marcin. Urodzić naród. Z problematyki czeskiej i stowackiej literatury kobiecej II połowy XIX wieku. Warszawa: WUW, 2008.

Hodrová, Daniela. Trýznivé město. Praha: Hynek, 1999.

Jedlička, Josef. České typy a jiné eseje. Praha: Plus, 2009.

Kołakowski, Leszek. Obecność mitu. Wrocław: Wydawnictwo Dolnośląskie, 1994.

Kratochvil, Jiří. Př́běhy př́běhủ. Brno: Atlantis, 1995.

Kundera, Milan. Czeski los. Przeł. Aleksander S. Jagodziński. Literatura na Świecie 9 (1990). S. 103-109.

Łotman Jurij, Uspieński Boris. O semiotycznym mechanizmie kultury. Przeł. J. Faryno. Semiotyka kultury. Red. E. Janus, M. R. Mayenowa. Warszawa: PIW, 1977. S. 147-170.

Macura, Vladimír. Znamení zrodu. České národní obrození jako kulturní typ. Jinočany: Nakladatelství H\&H, 1995.

Macura, Vladimír. Český sen. Praha: Nakladatelství Lidové noviny, 1999.

Macura, Vladimír. Ten, který bude. Praha: Hynek, 1999.

Nawrocki, Witold. "Kwestia czeska": tożsamość narodowa, literatura i polityka. Szkice i uwagi. Piotrków Trybunalski: Wydawnictwo Filii Kieleckiej WSP w Piotrkowie Trybunalskim, 2000.

Rak, Jiří. Bývali Čechové. České historické mýty a stereotypy. Praha: Nakladatelství H\&H, 1994.

Šmahelová, Hana. V síti dějin literatury národního obrození. Praha: Karolinum, 2011.

Urban, Josef (Miloš). Poslední tečka za Rukopisy (nová literatura faktu). Praha: Argo, 1998.

Urban, Miloš. Sedmikostelí. Gotický román z Prahy. Praha: Argo, 1999. 